Article

\title{
Synthesis, Design, and Structure-Activity Relationship of the Pyrimidone Derivatives as Novel Selective Inhibitors of Plasmodium falciparum Dihydroorotate Dehydrogenase
}

\author{
Le Xu ${ }^{1,+}$, Wenjie Li ${ }^{1,+}$, Yanyan Diao ${ }^{1,+}$, Hongxia Sun ${ }^{1}$, Honglin Li ${ }^{1}$, Lili Zhu ${ }^{1, *}$, \\ Hongchang Zhou ${ }^{2, *}$ and Zhenjiang Zhao ${ }^{1, *}$ \\ 1 Shanghai Key Laboratory of New Drug Design, School of Pharmacy, East China University of Science and \\ Technology, Shanghai 200237, China; 13162212770@163.com (L.X.); wjli12345@126.com (W.L.); \\ diaoyan1025@126.com (Y.D.); shx7982@163.com (H.S.); hlli@mail.shcnc.ac.cn (H.L.) \\ 2 Department of Microbiology, Medical School of Huzhou Teachers College, Huzhou 313000, China \\ * Correspondence: zhulfl@ecust.edu.cn (L.Z.); zhouhc529@zjhu.edu.cn (H.Z.); zhjzhao@ecust.edu.cn (Z.Z.); \\ Tel.: +86-21-6425-3379 (L.Z.); +86-21-6425-3962 (Z.Z.); Fax.: +86-21-64250213 (L.Z. \& Z.Z.) \\ + These authors contributed equally to this work.
}

Received: 2 May 2018; Accepted: 22 May 2018; Published: 24 May 2018

\begin{abstract}
The inhibition of Plasmodium falciparum dihydroorotate dehydrogenase (PfDHODH) potentially represents a new treatment option for malaria, as $P$. falciparum relies entirely on a de novo pyrimidine biosynthetic pathway for survival. Herein, we report a series of pyrimidone derivatives as novel inhibitors of $P f D H O D H$. The most potent compound, 26, showed high inhibition activity against $P f \mathrm{DHODH}\left(\mathrm{IC}_{50}=23 \mathrm{nM}\right)$, with $>400$-fold species selectivity over human dihydroorotate dehydrogenase $(h \mathrm{DHODH})$. The brand-new inhibitor scaffold targeting $P f \mathrm{DHODH}$ reported in this work may lead to the discovery of new antimalarial agents.
\end{abstract}

Keywords: P. falciparum; PfDHODH; pyrimidone; antimalarial agents

\section{Introduction}

Malaria is a mosquito-transmitted disease caused by protozoan parasites of the Plasmodium species [1,2]. The World Health Organization (WHO) estimated that there were nearly 216 million episodes of malaria and 445,000 deaths from malaria globally in 2016 [3]. Artemisinin combination therapies (ACTs) are the current first-line treatment for the deadliest form of malaria. However, the reduced efficacy of first-line treatments using artemisinin (compound 1) [4] and its derivatives (associated with Kelch 13 propeller protein mutations 7-95430) is now prevalent at the Cambodia-Thailand border and poses a serious threat to malaria control programs globally [5-8]. Chloroquine (compound 2) [9] and pyrimethamine (compound 3) [10], used as the mainstay of antimalarial chemotherapy, have now compromised the development of resistance [11]. To tackle the problem of drug resistance, various strategies have been developed to treat malaria $[12,13]$. For instance, Gilbert's group discovered that DDD107498 exhibits a novel spectrum of antimalarial activity against multiple life-cycle stages of the Plasmodium parasite [14].

Dihydroorotate dehydrogenase $(\mathrm{DHODH})$ is a rate-limiting enzyme that is required for the fourth step of de novo pyrimidine biosynthesis, converting dihydroorotate (DHO) to orotate (ORO) with the participation of the cofactors flavin mononucleotide (FMN) and ubiquinone (CoQ) [15-17]. Pyrimidine-based biosynthesis represents a basic biological and physiological process that is crucial for RNA and DNA production and cell proliferation. The mammalian cells generate pyrimidines through 
both de novo and salvage pathways for survival, while plasmodium parasites lack the necessary genes for the former, resulting in de novo pyrimidine synthesis as the vital pathway for the parasite [18]. Therefore, $P f D H O D H$ has been considered as the prospective target for the conquest of malaria [19-21]. DHODHs are divided into two families in the light of different amino acid sequences and coenzyme dependence. Human dihydroorotate dehydrogenase ( $h \mathrm{DHODH})$ and PfDHODH belong to family II, located on the inner mitochondrial membrane, which utilizes ubiquinone as the terminal oxidant [22].

Many $h \mathrm{DHODH}$ inhibitors have been corroborated to be effective against a number of diseases, such as cancer, rheumatoid arthritis (RA), psoriasis, and lupus erythematosus [23-25]. Some successes in identifying PfDHODH inhibitors on the basis of the modification of reported $h \mathrm{DHODH}$ inhibitors (e.g., compound 4) are well known [24]. Although sharing a highly conserved sequence in their C-terminal domains, $P f \mathrm{DHODH}$ and $h \mathrm{DHODH}$ possess huge variation in terms of the amino acid sequence in the N-terminal domain, which facilitates further discovery of specific inhibitors of PfDHODH [22]. In addition, many different kinds of selective and promising PfDHODH inhibitors have been developed through target-based high-throughput screening (e.g., compounds 5-7) (as shown in Figure 1) [26-28]. What is more, X-ray structures of PfDHODH in complex with some representative compounds were used to develop more potent, non-cross-resistant selective antimalarial agents, leading to the identification of compound 8 (DSM 256), which has progressed in phase II clinical trials [29]. Furthermore, compound 9 (DSM 421) is a preclinical development candidate for the treatment of malaria, which has improved solubility, lower intrinsic clearance, and increased plasma exposure after oral dosing compared with DSM 265 [30].

In our previous work, we reported the identification of compound 10 as a PfDHODH inhibitor by the structure-based virtual screening strategy integrating molecular Glide docking with Prime/MM-GBSA re-scoring on the basis of the complex crystal structure of compound 7 (DSM 1) with PfDHODH (PDB code 3I65) [31]. Compound 10 selectively inhibited PfDHODH ( $\mathrm{IC}_{50}=6 \mathrm{nM}$, with $>14,000$-fold species selectivity over $h \mathrm{DHODH}$ ) and parasite growth in vitro ( $\mathrm{IC}_{50}$ of 15 and $18 \mathrm{nM}$ against 3D7 and Dd2 cells, respectively), but it was less effective in vivo as a result of its poor metabolic properties [31]. Recently, several pyrimidone derivatives based on compound 10 as a lead compound were obtained in this work and showed high selectivity over $h \mathrm{DHODH}$, suggesting potential applications as novel antimalarial agents.

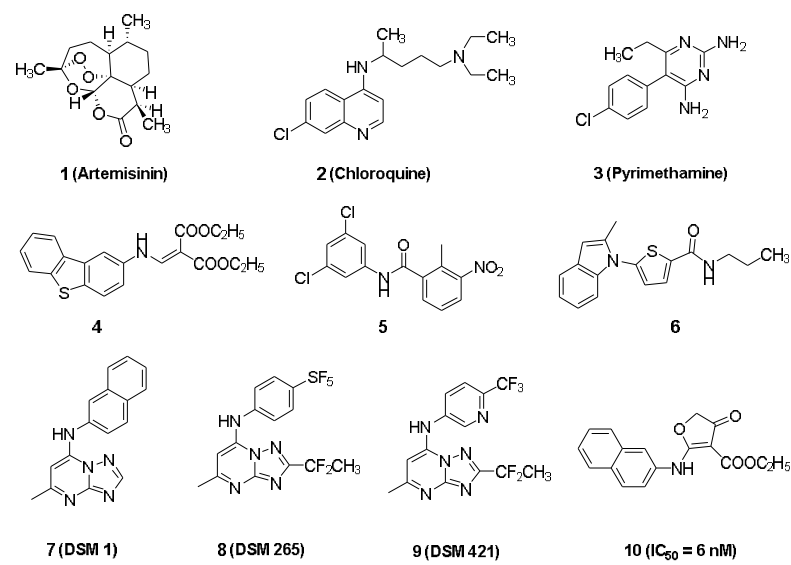

Figure 1. Structures of reported antimalarial agents 1-3, PfDHODH inhibitors 4-9, and the lead compound 10 in this study.

\section{Results and Discussion}

\subsection{Proposed Binding Pose of Lead Compound 10 in the Ubiquinone Binding Pocket of PfDHODH}

To thoroughly explore the binding mode of compound $\mathbf{1 0}$ in the ubiquinone binding pocket of PfDHODH, flexible induced-fit docking [32] was implemented in Maestro v10.1 on the basis of the 
crystal structure of PfDHODH in complex with DSM1 (PDB code 3I65). As shown in Figure 2A, the entrance of the ubiquinone binding channel is relatively closed in $P f D H O D H$; thus compound 10 is totally buried inside the protein. The naphthyl group sits in the region close to the entrance and fits the pocket well through hydrophobic interactions with adjacent residues such as Met536, Leu197, Leu240, Ile237, and Phe227. The ester group is located almost in the same plane of the dihydrofuranone moiety, with its carbonyl group pointing in the same direction as that on the dihydrofuranone ring. Both the carbonyl groups could form favorable hydrogen bond interactions with Arg265. Additionally, the binding pocket near Arg265 has a strongly positive electrostatic surface potential, which is complementary to the two carbonyl groups with negative electrostatic potential (the minimum ESP values of the two oxygen atoms are both $-58.53 \mathrm{kcal} / \mathrm{mol}$ ). An additional hydrogen bond is presumably formed between the bridging nitrogen atom and His185, which is considered to be essential for the activities and selectivities of PfDHODH inhibitors. The ethyl group extends to the cavity near the FMN binding site, forming beneficial hydrophobic effects with residues Ile263 and Ile272 that could help to enhance the potency of compound $\mathbf{1 0 .}$

\subsection{The Structural Optimization Strategy using the Lead Compound $\mathbf{1 0}$}

According to rational drug design and the proposed binding mode described above, the desired PfDHODH inhibitor should embrace two functional parts, a hydrogen bond forming "head" linked via a nitrogen to a hydrophobic "tail". In the hydrophilic pocket composed by subsites 2 and 3, the functional groups (e.g., carbonyl groups) could form hydrogen bonds with the guanidine group of Arg265, which is indispensable for maintaining the inhibitory activity against $P f D H O D H$. As for the hydrophobic pocket of subsite 1, the naphthyl ring is more suitable compared with the reported PfDHODH inhibitors in terms of the size that the cavity can accommodate [31]. Consequently, with the attempt to discover more potent $P f D H O D H$ inhibitors for further pharmacological study, as well as to verify the structure-activity relationship, an optimization strategy using the lead compound 10 was carried out through three modifications: (1) hydrophobic modification on the aromatic ring, (2) hydrophilic group modification on the dihydrofuranone ring, and (3) cyclization forming a new scaffold to enhance the stability (as shown in Figure 3).

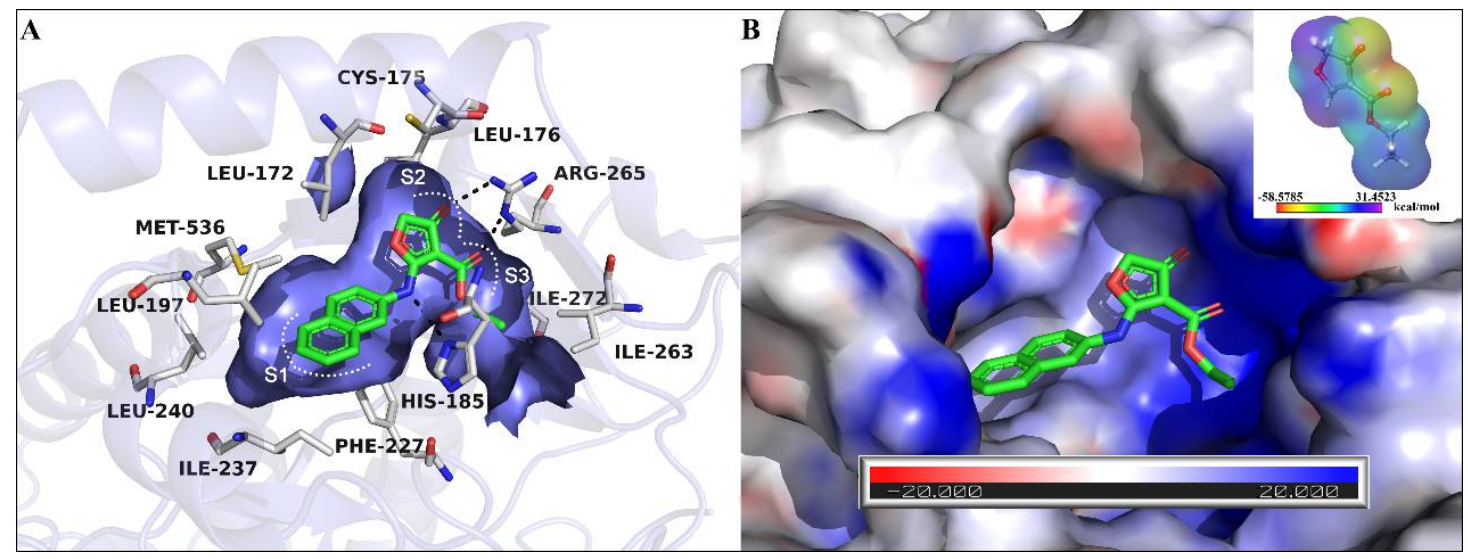

Figure 2. (A) Proposed binding pose of lead compound 10 in the ubiquinone binding pocket of PfDHODH. Key residues around the binding pocket are shown as white lines and ligand is shown as green sticks. The hydrogen bonds are labeled as black dashes. (B) Electrostatic complementarity between the dihydrofuranone moiety of compound $\mathbf{1 0}$ and the binding site near Arg265. The electrostatic potential surface of PfDHODH shown between -20 (red) and $+20 \mathrm{kT} / \mathrm{e}$ (blue) was calculated using APBS tool [33-35]. The ESP of the dihydrofuranone fragment was calculated by Jaguar with DFT at B3LYP/cc-pVTZ(-f) level. 


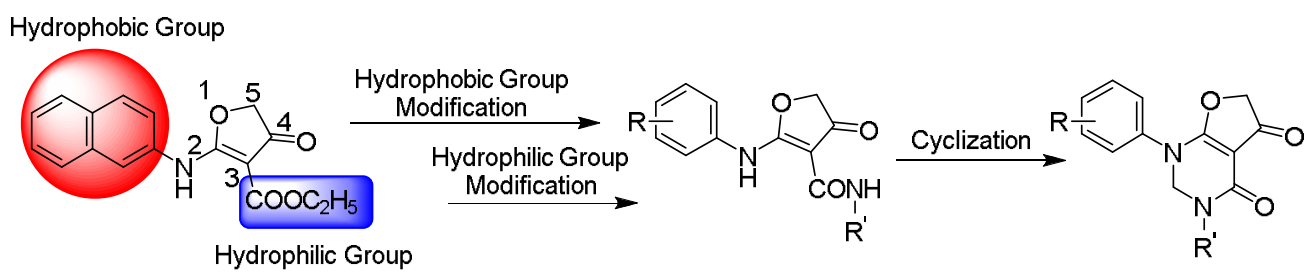

Figure 3. Diagram for the structural optimization strategy.

\subsection{Chemistry}

The lead compound 10, with a dihydrofuranone core, was regarded as the well-designed structural foundation in our initial optimization. First, we replaced the easily metabolized ester group with an amide group. The preparation of the amide derivatives started with compound 11, which served as an important intermediate (Scheme 1). To avoid byproducts during ester hydrolysis, the temperature must be controlled accurately [36]. With the purpose to further study the structure-activity relationships and improve the pharmacological properties, a series of dihydrofuranone derivatives were designed and synthesized (Scheme 1) [37]. Amides were synthesized in the presence of HOBt, EDCI, and DIPEA. Compound 20 was obtained by replacing alkylamines with $80 \%$ hydrazine hydrate and using $\mathrm{N}$, $\mathrm{N}$-carbonyldiimidazole (CDI) in the routes depicted in Scheme 2.

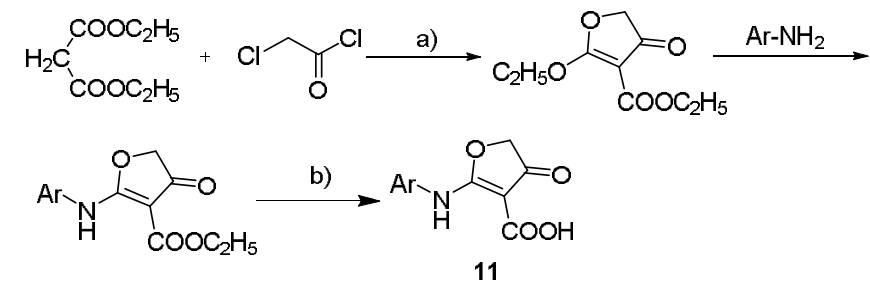

Scheme 1. Reagents and conditions: (a) sodium hydride, diethyl malonate, 2-chloroacetyl chloride, and $\mathrm{THF}$, at $\mathrm{rt}$ for $1 \mathrm{~h}$, at $40-45^{\circ} \mathrm{C}$ for $5 \mathrm{~h}$, and under reflux for $18 \mathrm{~h}$; (b) $\mathrm{LiOH}-\mathrm{H}_{2} \mathrm{O}, \mathrm{MeOH}-\mathrm{H}_{2} \mathrm{O}\left(55-60{ }^{\circ} \mathrm{C}\right)$ for $12 \mathrm{~h}$.

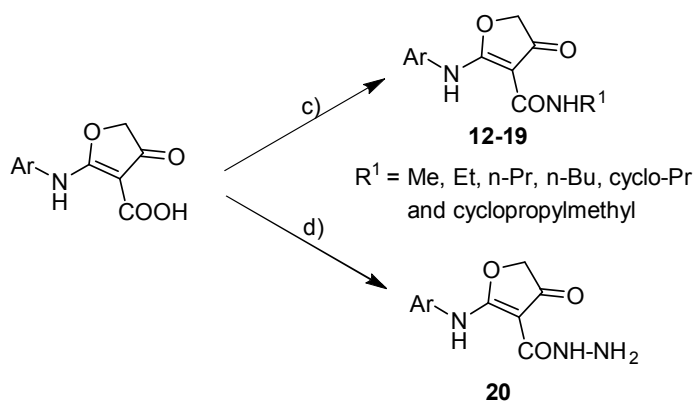

Scheme 2. Reagents and conditions: (c) $\mathrm{RNH}_{2}, \mathrm{HOBt}, \mathrm{EDC}$, DIPEA, and $\mathrm{CH}_{2} \mathrm{Cl}_{2}$, overnight at rt; (d) $80 \%$ hydrazine hydrate and $N, N^{\prime}$-carbonyldiimidazole (CDI), overnight at rt.

According to the predicted binding pose of the lead compound 10, two carbonyl groups that orient in the same direction are necessary for the potent activity. Therefore, we used paraformaldehyde to form the rigid six-membered ring that could fix the two carbonyl group orientations well in space. For this reason, compounds $\mathbf{1 3}-\mathbf{1 6 , 1 8}$ and 20 were subsequently transformed to the pyrimidone derivatives 21-26 by cyclization (Scheme 3) [38]. All structures of the final products were determined by spectroscopic techniques. 


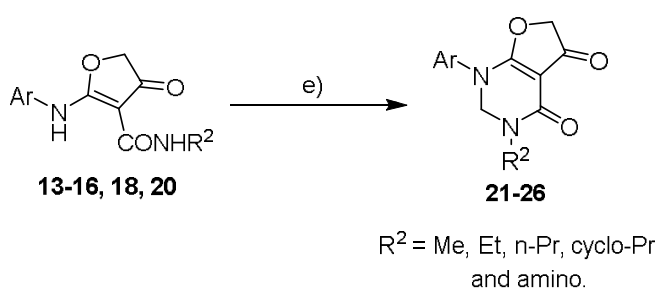

Scheme 3. Reagents and conditions: (e) paraformaldehyde, $\mathrm{NaOH}$ and $\mathrm{EtOH}$, at $\mathrm{rt}$ for $1 \mathrm{~h}$ and at $70^{\circ} \mathrm{C}$ for another $8 \mathrm{~h}$.

\subsection{Inhibitory Activities against PfDHODH and SAR Study}

\subsubsection{Hydrophobic Group Modification}

Because the $P f \mathrm{DHODH}$ inhibition potency was particularly sensitive to the substitution pattern at the phenyl ring [39], an optimization strategy was carried out: modification on the hydrophobic moiety substituted by phenyl (compound 12) and 5-aminoindan (compound 13). Compared with compounds 12 and 13, compound 15 containing a 2-naphthyl moiety was more active against $P f D H O D H$, with an $\mathrm{IC}_{50}$ value of $4.8 \mu \mathrm{M}$. Notably, the phenyl ring as the hydrophobic group reversed the species selectivity of compound 12, which showed an $\mathrm{IC}_{50}$ value of $2.4 \mu \mathrm{M}$ against $h \mathrm{DHODH}$ and was inactive against $P f \mathrm{DHODH}$. The above results validate that using 2-naphthyl as the hydrophobic group is beneficial to keep a high potency against $P f D H O D H$ (as shown in Table 1).

\subsubsection{Hydrophilic Group Modification}

On the basis of previous results using 2-naphthyl as the hydrophobic group ( $\mathrm{R} 1=2$-naphthyl), compounds $\mathbf{1 1}$ and 14-20 were obtained. In this section, the emphasis is on evaluating the effect of the structural changes of the hydrophilic group on the inhibitory activity against $P f D H O D H$. In the absence of an ethoxycarbonyl group on the dihydrofuranone scaffold, compound $\mathbf{1 1}$ displayed lower inhibitory activity in comparison with 10 , which suggests that it would be strongly disfavored if the derivatives do not possess any substituent at the 3-position of the scaffold (as shown in Figure 3). Next, derivatives with different amide groups (compounds 12-20) were synthesized to identify the optimal alkyl chain that could fit the binding cavity. Amides with different chain lengths were introduced to investigate their effects on the inhibitory activities. Compared with compound $\mathbf{1 5}\left(\mathrm{IC}_{50}=4.8 \mu \mathrm{M}\right)$, compound $14\left(\mathrm{IC}_{50}=9 \mu \mathrm{M}\right)$ showed a decline in the inhibitory activity against $P f D H O D H$; the reason may be attributed to the shorter alkyl chain, which mismatched the size of the cavity. However, compounds 16 and 17 lost their activities because of the long alkyl chains, which may have resulted in collisions with residues such as Ile263 and Ile272. Compound 18 inhibited PfDHODH with an $\mathrm{IC}_{50}$ value of $6 \mu \mathrm{M}$, which indicated that the size of the cyclopropyl was suitable for the hydrophobic cavity to some extent. However, compound 19 with cyclopropanemethylamine lost the inhibitory activity against $P f \mathrm{DHODH}$ owing to the increased size of the alkyl side chain. According to our present study, ethyl and cyclopropyl are well matched with the size and shape of the cavity. Compound 20 equipped with the amino displayed an $\mathrm{IC}_{50}$ value of $70 \mathrm{nM}$, likely a result of forming a hydrogen bond interaction with the adjacent residue His185. Therefore, a suitable substituent group in the 3-position and the amino group forming the hydrogen bonding interaction with His185 in PfDHODH played a vital role for potent activities of $P f$ DHODH inhibitors (as shown in Table 1). 
Table 1. Structure and activity profiles of compounds 11-26 against $P f D H O D H$ and human DHODH $(h \mathrm{DHODH})$ in enzyme assays.

\begin{tabular}{|c|c|c|c|c|}
\hline & & $\mathrm{R}^{2}$ & \multicolumn{2}{|c|}{$\mathrm{IC}_{50}(\mu \mathrm{M})$} \\
\hline Compound & $\mathrm{R}^{1}$ & $\mathrm{R}^{2}$ & PfDHODH ${ }^{a}$ & $h \mathrm{DHODH}^{b}$ \\
\hline 11 & 2-Naphthyl & $\mathrm{COOH}$ & $0.106 \pm 0.009$ & $>10$ \\
\hline 12 & Phenyl & $\mathrm{CONHCH}_{2} \mathrm{CH}_{3}$ & $>10$ & $2.4 \pm 0.1$ \\
\hline 13 & 5-Aminoindan & $\mathrm{CONHCH}_{2} \mathrm{CH}_{3}$ & $>10$ & $>10$ \\
\hline 14 & 2-Naphthyl & $\mathrm{CONHCH}_{3}$ & $9 \pm 1$ & $>10$ \\
\hline 15 & 2-Naphthyl & $\mathrm{CONHCH}_{2} \mathrm{CH}_{3}$ & $4.8 \pm 0.4$ & $>10$ \\
\hline 16 & 2-Naphthyl & $\mathrm{CONHCH}_{2} \mathrm{CH}_{2} \mathrm{CH}_{3}$ & $>10$ & $>10$ \\
\hline 17 & 2-Naphthyl & $\mathrm{CONHCH}_{2} \mathrm{CH}_{2} \mathrm{CH}_{2} \mathrm{CH}_{3}$ & $>10$ & $>10$ \\
\hline 18 & 2-Naphthyl & CONH & $6 \pm 1$ & $>10$ \\
\hline 19 & 2-Naphthyl & $\mathrm{CONH}$ & $>10$ & $>10$ \\
\hline 20 & 2-Naphthyl & $\mathrm{CONH}-\mathrm{NH}_{2}$ & $0.07 \pm 0.01$ & $>10$ \\
\hline 21 & 5-Aminoindan & $\mathrm{CH}_{2} \mathrm{CH}_{3}$ & $>10$ & $>10$ \\
\hline 22 & 2-Naphthyl & $\mathrm{CH}_{3}$ & $8 \pm 1$ & $>10$ \\
\hline 23 & 2-Naphthyl & $\mathrm{CH}_{2} \mathrm{CH}_{3}$ & $4 \pm 1$ & $>10$ \\
\hline 24 & 2-Naphthyl & $\mathrm{CH}_{2} \mathrm{CH}_{2} \mathrm{CH}_{3}$ & $12 \pm 6$ & $>10$ \\
\hline 25 & 2-Naphthyl & $\stackrel{\text { CONH }}{\nabla}$ & $5 \pm 1$ & $>10$ \\
\hline 26 & 2-Naphthyl & $\mathrm{NH}_{2}$ & $0.023 \pm 0.001$ & $>10$ \\
\hline DSM1 & - & - & $0.042 \pm 0.004$ & - \\
\hline
\end{tabular}

${ }^{\mathrm{a}}$ The $\mathrm{IC}_{50}$ values of the compounds against $P f \mathrm{DHODH}$, in vitro assay, $\mu \mathrm{M}$. ${ }^{\mathrm{b}} \mathrm{The}_{\mathrm{IC}} \mathrm{C}_{50}$ values of the compounds against $h \mathrm{DHODH}$, in vitro assay, $\mu \mathrm{M}$.

\subsubsection{Cyclization Forming a New Scaffold}

After cyclization forming a new scaffold, a six-membered ring could stabilize two carbonyl groups orientated in the same direction, which formed hydrogen bonds with Arg265 of PfDHODH. It is clear that compound 22-26 showed higher inhibitory activities compared with the corresponding uncyclized amide mimics (Table 1). The reason for all these compounds with the new scaffold presenting high inhibitory activities against $P f D H O D H$ can be elucidated from the predicted binding pose in our work. The predicted binding pose of compound $\mathbf{1 0}$ revealed that the bridge nitrogen atom not only linked the hydrophilic group to the hydrophobic group, but also interacted with His185 via a hydrogen bond, which is very important for the inhibitory activity. We designed new PfDHODH inhibitors that contained a new hydrogen bond donor interacting with His185. In our present study, compound 26 was the most potent candidate against $P f \mathrm{DHODH}$, which had an $\mathrm{IC}_{50}$ value equal to $23 \mathrm{nM}$ and was 3-fold more active than compound 20. The predicted binding pose of compound $\mathbf{2 6}$ is shown in Figure 4. Two carbonyl groups formed hydrogen bonds with residues Arg265, and the nitrogen atom in the amino group formed an additional hydrogen bond with His185. Briefly, cyclization enhanced the structural stability and maintained the hydrogen bond interactions between the two carbonyl groups and the key residue Arg265. 


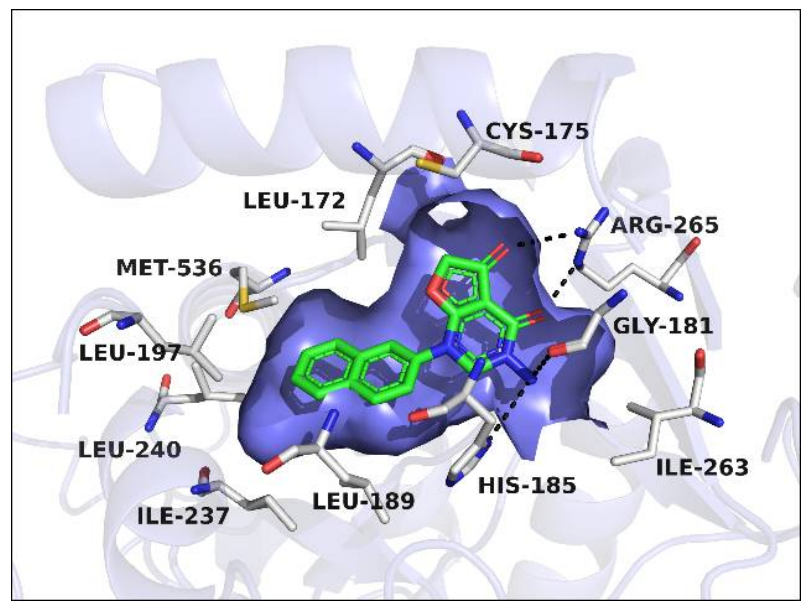

Figure 4. Proposed binding pose of compound 26 in the ubiquinone binding pocket of PfDHODH. Key residues around the binding pocket are shown as white lines, and ligand is shown as green sticks. The hydrogen bonds are labeled as black dashes.

\section{Materials and Methods}

All chemical reagents and solvents were obtained from commercial sources and were used without further purification. Melting points (Mp's) were recorded on a WRS-1B-digital melting point apparatus and are uncorrected. High-resolution electron mass spectra (ESI-TOF) were produced using a Micromass LC-TOF spectrometer (Waters, Milford, MA, US). ${ }^{1} \mathrm{H}$ - and ${ }^{13} \mathrm{C}-\mathrm{NMR}$ spectra were recorded on a Bruker AM-400 $\left({ }^{1} \mathrm{H}\right.$ at $400 \mathrm{MHz} ;{ }^{13} \mathrm{C}$ at $\left.100 \mathrm{MHz}\right)$ spectrometer (Bruker, Fallanden, Switzerland)) with DMSO- $d_{6}$ or $\mathrm{CDCl}_{3}$ as the solvent and TMS as the internal standard. Chemical shifts are reported in $\delta$ (parts per million). Analytical thin-layer chromatography (TLC) was performed on precoated plates (silica gel 60 F254), and spots were visualized with ultraviolet (UV) light. The following are used to explain the multiplicities: $\mathrm{s}=$ singlet, $\mathrm{d}=$ doublet, $\mathrm{t}=$ triplet, $\mathrm{q}=$ quartet, $\mathrm{m}=$ multiplet, coupling constant $(\mathrm{Hz})$, and integration.

\subsection{In Vitro Enzyme Assay}

Protein expression, purification, and enzyme activity determination of PfDHODH (Phe158-Ser569) and $h \mathrm{DHODH}$ (Met30-Arg396) were performed according to our previous work [31]. The enzymes were diluted to a final concentration of $10 \mathrm{nM}$ using the assay buffer containing $50 \mathrm{mM}$ HEPES (pH 8.0), $150 \mathrm{mM} \mathrm{KCl}, 0.1 \%$ Triton X-100 supplemented with $100 \mu \mathrm{M} \mathrm{UQ}_{0}$, and $120 \mu \mathrm{M}$ DCIP. The mixture was transferred into a 96-well plate and incubated with or without various amounts of inhibitors for $5 \mathrm{~min}$ at room temperature, and then the dihydroorotate was added to a final concentration of $500 \mu \mathrm{M}$ to initiate the reaction. The reaction was monitored by measuring the decrease in DCIP in the absorption at $600 \mathrm{~nm}$ at each $30 \mathrm{~s}$ over a period of $6 \mathrm{~min}$. Brequinar and DSM1 were measured as the positive controls for $h \mathrm{DHODH}$ and $P f \mathrm{DHODH}$, respectively. Percent inhibition relative to no inhibitor control was calculated by $\left(1-\mathrm{V}_{\mathrm{i}} / \mathrm{V}_{0}\right) \times 100$. For the determination of the $\mathrm{IC}_{50}$ value of the inhibitor, eight or nine different concentrations were applied. Each inhibitor concentration point was tested in triplicate, and the $\mathrm{IC}_{50}$ values were calculated using the sigmoidal fitting option of the program Origin 8.0 (Originlab, Northampton, MA, US). 


\subsection{Chemistry Experiment}

\subsubsection{General Procedure for the Synthesis of Intermediates}

Synthesis of the ethyl 2-(substituted arylamino)-4-oxo-4,5-dihydrofuran-3 carboxylate

Diethyl malonate $(63 \mathrm{mmol})$ dissolved in dry THF $(15 \mathrm{~mL})$ was added to a stirred solution of sodium hydride $(71 \mathrm{mmol}, 60 \%)$ in dry THF $(10 \mathrm{~mL})$, and the mixture was stirred for $20 \mathrm{~min}$ at $0-10^{\circ} \mathrm{C}$. Then the reaction mixture was stirred at room temperature for $10 \mathrm{~min}$, and 2-chloroacetyl chloride (32 mmol) in dry THF (15 mL) was added. The solution was kept at room temperature for $1 \mathrm{~h}$ and at $40-45{ }^{\circ} \mathrm{C}$ for another $5 \mathrm{~h}$, and substituted aniline $(11 \mathrm{mmol})$ in dry THF $(100 \mathrm{~mL})$ was added dropwise over $20 \mathrm{~min}$. The reaction mixture was stirred at room temperature overnight and then heated under reflux for $18 \mathrm{~h}$. After excess THF was evaporated off, the resulting residue was extracted with EtOAc $(3 \times 10 \mathrm{~mL})$ and washed with brine $(3 \times 10 \mathrm{~mL})$. The organic layer was dried $\left(\mathrm{Na}_{2} \mathrm{SO}_{4}\right)$, concentrated under reduced pressure, and purified by column chromatography (PE: 1:1 v/v EtOAc) with 30-35\% yield as a white solid.

Synthesis of the 2-(substituted arylamino)-4-oxo-4,5 dihydrofuranone-3-carboxylic acid

$\mathrm{LiOH}-\mathrm{H}_{2} \mathrm{O}(10 \mathrm{mmol})$ was slowly added to a solution of ethyl 2-(substituted arylamino)4-oxo-4,5-dihydrofuran-3-carboxylate (2 mmol) in $\mathrm{MeOH}-\mathrm{H}_{2} \mathrm{O}\left(18 \mathrm{~mL}, 5: 1 v / v \mathrm{MeOH} / \mathrm{H}_{2} \mathrm{O}\right)$ at $0{ }^{\circ} \mathrm{C}$ over $30 \mathrm{~min}$. The reaction mixture was allowed to warm to $55-60{ }^{\circ} \mathrm{C}$ for $12 \mathrm{~h}$ with stirring. After $\mathrm{MeOH}$ was evaporated off, the aqueous residual was acidified to $\mathrm{pH} 1-2$ with $1 \mathrm{~N} \mathrm{HCl}$ and precipitated solid was filtered, washed with water, and dried under vacuum with $70-80 \%$ yield as a yellow solid.

Synthesis of compound $\mathbf{1 1}$

$\mathrm{LiOH}-\mathrm{H}_{2} \mathrm{O}$ (10 mmol) was slowly added to a solution of ethyl 2-(naphthalen-2-ylamino)-4-oxo-4,5-dihydrofuran-3-carboxylate (2 mmol) in $\mathrm{MeOH}-\mathrm{H}_{2} \mathrm{O}(18 \mathrm{~mL}, 5: 1$ $v / v \mathrm{MeOH} / \mathrm{H}_{2} \mathrm{O}$ ) at $0{ }^{\circ} \mathrm{C}$ over $15 \mathrm{~min}$. The reaction mixture was allowed to warm to $55-60{ }^{\circ} \mathrm{C}$ for $12 \mathrm{~h}$ with stirring. After $\mathrm{MeOH}$ was evaporated off, the aqueous residual was acidified to $\mathrm{pH} 1-2 \mathrm{with} 1 \mathrm{~N}$ $\mathrm{HCl}$ and precipitated solid was filtered, washed with water, and dried under vacuum with 70-80\% yield as a yellow solid.<smiles>O=C(O)C1=C(Nc2ccc3ccccc3c2)OCC1=O</smiles>

2-(Naphthalen-2-ylamino)-4-oxo-4,5-dihydrofuran-3-carboxylic acid (11); Mp: 164.4-165.0 ${ }^{\circ} \mathrm{C} .{ }^{1} \mathrm{H}-\mathrm{NMR}$ (400 MHz, DMSO-d $\left.{ }_{6}\right): \delta 11.47(\mathrm{~s}, 1 \mathrm{H}), 10.55(\mathrm{~s}, 1 \mathrm{H}), 8.08-7.89(\mathrm{~m}, 4 \mathrm{H}), 7.62-7.40(\mathrm{~m}, 3 \mathrm{H}), 4.07(\mathrm{~s}, 2 \mathrm{H})$. ${ }^{13}$ C-NMR (100 MHz, DMSO-d $\left.d_{6}\right): \delta$ 197.3, 183.3, 165.3, 135.1, 133.2, 132.5, 130.0, 128.4, 128.2, 127.6, 127.4, 123.7, 123.4, 98.6, 38.7. HRMS (ESI): $[\mathrm{M}+\mathrm{H}]^{+}$calcd for $\mathrm{C}_{15} \mathrm{H}_{11} \mathrm{NO}_{4}, 270.0688$; found, 270.0688 .

\subsubsection{General Procedure for Target Compounds 12-19}

HOBt $(1.1 \mathrm{mmol})$ EDC (1.1 mmol), and DIPEA $(1 \mathrm{mmol})$ were added to a solution of amine (1 mmol) and 2-(substituted amino)-4-oxo-4,5 dihydrofuranone-3-carboxylic acid (1 mmol) in dry DCM $(5 \mathrm{~mL})$ at $0{ }^{\circ} \mathrm{C}$. The reaction mixture was stirred overnight at room temperature and then washed with $5 \%$ aqueous $\mathrm{HCl}(2 \times 15 \mathrm{~mL}), 5 \%$ aqueous $\mathrm{NaHCO}_{3}(2 \times 15 \mathrm{~mL})$, and brine $(2 \times 15 \mathrm{~mL})$ and was dried $\left(\mathrm{Na}_{2} \mathrm{SO}_{4}\right)$ and concentrated under reduced pressure with purification by column chromatography (PE: 6:1, v/v EtOAc) with 20-25\% yield as a white solid. 
<smiles>CCNC(=O)C1=C(Nc2ccccc2)OCC1=O</smiles>

N-Ethyl-4-oxo-2-(phenylamino)-4,5-dihydrofuran-3-carboxamide (12); Mp: 146.9-147.4 ${ }^{\circ} \mathrm{C} .{ }^{1} \mathrm{H}-\mathrm{NMR}(400$ $\left.\mathrm{MHz}_{\mathrm{CDCl}}\right): \delta 11.51(\mathrm{~s}, 1 \mathrm{H}), 7.47(\mathrm{t}, J=8.0 \mathrm{~Hz}, 2 \mathrm{H}), 7.37(\mathrm{~d}, J=8.0 \mathrm{~Hz}, 2 \mathrm{H}), 7.35(\mathrm{~s}, 1 \mathrm{H}), 4.39(\mathrm{q}, J=7.2$ $\mathrm{Hz}, 2 \mathrm{H}), 3.67$ (s, 2H), 1.42 (t, $J=7.2 \mathrm{~Hz}, 3 \mathrm{H}) .{ }^{13} \mathrm{C}-\mathrm{NMR}\left(100 \mathrm{MHz}, \mathrm{DMSO}-d_{6}\right): \delta 191.0,183.3,165.5$, 137.8, 130.0, 128.3, 125.6, 97.4, 59.7, 38.4, 14.9. HRMS (ESI): $[\mathrm{M}+\mathrm{H}]^{+}$calcd for $\mathrm{C}_{13} \mathrm{H}_{14} \mathrm{~N}_{2} \mathrm{O}_{3}, 247.1004$; found, 247.1009 .<smiles>CCNC(=O)C1=C(Nc2ccc3c(c2)CCC3)OCC1=O</smiles>

2-[(2,3-Dihydro-1H-inden-5-yl)amino]-N-ethyl-4-oxo-4,5-dihydrofuran-3-carboxamide (13); Mp: 127.7-128.2 ${ }^{\circ} \mathrm{C} .{ }^{1} \mathrm{H}-\mathrm{NMR}\left(400 \mathrm{MHz}, \mathrm{DMSO}-d_{6}\right): \delta 11.08(\mathrm{~s}, 1 \mathrm{H}), 7.32(\mathrm{~d}, J=8.0 \mathrm{~Hz}, 1 \mathrm{H}), 7.27(\mathrm{~s}, 1 \mathrm{H}), 7.16(\mathrm{~d}, J=8.0$ $\mathrm{Hz}, 1 \mathrm{H}), 4.22(\mathrm{q}, J=7.2 \mathrm{~Hz}, 2 \mathrm{H}), 3.65(\mathrm{~s}, 2 \mathrm{H}), 2.89(\mathrm{t}, J=7.6 \mathrm{~Hz}, 4 \mathrm{H}), 2.09-2.02(\mathrm{~m}, 2 \mathrm{H}), 1.26(\mathrm{t}, J=7.2 \mathrm{~Hz}$, 3H). ${ }^{13} \mathrm{C}-\mathrm{NMR}\left(100 \mathrm{MHz}\right.$, DMSO-d $\left.d_{6}\right): \delta$ 190.9, 183.5, 165.6, 145.7, 144.2, 135.8, 125.4, 123.6, 121.6, 97.1, 59.7, 38.4, 32.8, 32.4, 25.7, 14.9. HRMS (ESI): $[\mathrm{M}+\mathrm{H}]^{+}$calcd for $\mathrm{C}_{16} \mathrm{H}_{18} \mathrm{~N}_{2} \mathrm{O}_{3}, 287.1317$; found, 287.1320.<smiles>CNC(=O)C1=C(Nc2ccc3ccccc3c2)OCC1=O</smiles>

N-Methyl-2-(naphthalen-2-ylamino)-4-oxo-4,5-dihydrofuran-3-carboxamide (14); $\mathrm{Mp:} \quad 126.3-126.9{ }^{\circ} \mathrm{C}$. ${ }^{1} \mathrm{H}-\mathrm{NMR}\left(400 \mathrm{MHz}_{\mathrm{CDCl}}\right): \delta 11.65(\mathrm{~s}, 1 \mathrm{H}), 7.67-7.79(\mathrm{~m}, 4 \mathrm{H}), 7.42-7.51(\mathrm{~m}, 3 \mathrm{H}), 4.62(\mathrm{~s}, 2 \mathrm{H}), 3.32$ (s, 3H). ${ }^{13} \mathrm{C}-\mathrm{NMR}\left(100 \mathrm{MHz}, \mathrm{CDCl}_{3}\right): \delta 192.4,181.3,165.9,133.6,134.9,133.4,131.8,129.8,127.8,127.2$, 126.5, 121.8, 120.6, 99.9, 78.3, 35.7. HRMS (ESI): $[\mathrm{M}+\mathrm{H}]^{+}$calcd for $\mathrm{C}_{18} \mathrm{H}_{14} \mathrm{~N}_{2} \mathrm{O}_{3}, 283.1004$; found, 283.1011.<smiles>CCNC(=O)C1=C(Nc2ccc3ccccc3c2)OCC1=O</smiles>

N-Ethyl-2-(naphthalen-2-ylamino)-4-oxo-4,5-dihydrofuran-3-carboxamide (15); $\mathrm{Mp}: \quad 121.8-123.0{ }^{\circ} \mathrm{C}$. ${ }^{1} \mathrm{H}-\mathrm{NMR}\left(400 \mathrm{MHz} \mathrm{CDCl}_{3}\right): \delta 11.05(\mathrm{~s}, 1 \mathrm{H}), 7.88-7.79(\mathrm{~m}, 4 \mathrm{H}), 7.53-7.44(\mathrm{~m}, 3 \mathrm{H}), 4.78(\mathrm{~s}, 2 \mathrm{H}), 3.40-3.47$ $(\mathrm{m}, 2 \mathrm{H}), 1.24(\mathrm{t}, J=7.2 \mathrm{~Hz}, 3 \mathrm{H}) .{ }^{13} \mathrm{C}-\mathrm{NMR}\left(100 \mathrm{MHz}, \mathrm{CDCl}_{3}\right): \delta 190.5,176.5,164.3,133.6,132.7,131.1$, $129.5,127.7,127.6,127.0,125.9,120.2,118.1,89.5,75.7,33.4,15.1$. HRMS (ESI): $[\mathrm{M}+\mathrm{H}]^{+}$calcd for $\mathrm{C}_{17} \mathrm{H}_{16} \mathrm{~N}_{2} \mathrm{O}_{3}$, 297.1239; found, 297.1241.<smiles>CCCNC(=O)C1=C(Nc2ccc3ccccc3c2)OCC1=O</smiles>

2-(Naphthalen-2-ylamino)-4-oxo-N-propyl-4,5-dihydrofuran-3-carboxamide (16); $\mathrm{Mp}: \quad 126.2-127.2{ }^{\circ} \mathrm{C}$. ${ }^{1} \mathrm{H}-\mathrm{NMR}\left(400 \mathrm{MHz}, \mathrm{CDCl}_{3}\right): \delta 12.95(\mathrm{~s}, 1 \mathrm{H}), 8.91(\mathrm{~s}, 1 \mathrm{H}), 7.92-7.84(\mathrm{~m}, 4 \mathrm{H}), 7.56-7.29(\mathrm{~m}, 3 \mathrm{H}), 3.75$ $(\mathrm{s}, 2 \mathrm{H}), 3.37(\mathrm{q}, J=6.4 \mathrm{~Hz}, 2 \mathrm{H}), 1.69-1.63(\mathrm{~m}, 2 \mathrm{H}), 1.02(\mathrm{t}, J=7.2 \mathrm{~Hz}, 3 \mathrm{H}) .{ }^{13} \mathrm{C}-\mathrm{NMR}\left(100 \mathrm{MHz}, \mathrm{CDCl}_{3}\right)$ : $\delta$ 193.8, 181.3, 165.9, 135.0, 133.4, 131.8, 129.8, 127.8, 127.2, 126.5, 121.8, 120.6, 99.6, 40.1, 38.5, 23.0, 11.5 . HRMS (ESI): $[\mathrm{M}+\mathrm{H}]^{+}$calcd for $\mathrm{C}_{18} \mathrm{H}_{18} \mathrm{~N}_{2} \mathrm{O}_{3}, 333.1317$; found, 333.1311 . 


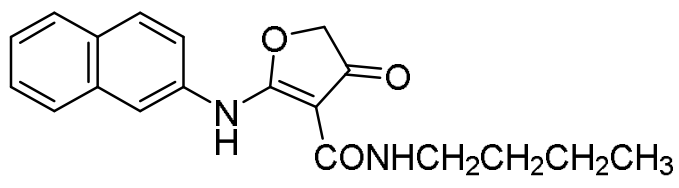

2-(Naphthalen-2-ylamino)-4-oxo-N-propyl-4,5-dihydrofuran-3-carboxamide (17); $\mathrm{Mp:} \quad 140.1-141.0{ }^{\circ} \mathrm{C}$. ${ }^{1} \mathrm{H}-\mathrm{NMR}\left(400 \mathrm{MHz}, \mathrm{CDCl}_{3}\right): \delta 12.94(\mathrm{~s}, 1 \mathrm{H}), 8.89(\mathrm{~s}, 1 \mathrm{H}), 7.93-7.84(\mathrm{~m}, 4 \mathrm{H}), 7.58-7.44(\mathrm{~m}, 3 \mathrm{H}), 3.75$ $(\mathrm{s}, 2 \mathrm{H}), 3.41(\mathrm{q}, J=6.8 \mathrm{~Hz}, 2 \mathrm{H}), 1.66-1.59(\mathrm{~m}, 2 \mathrm{H}), 1.50-1.41(\mathrm{~m}, 2 \mathrm{H}), 0.99(\mathrm{t}, J=7.2 \mathrm{~Hz}, 3 \mathrm{H}) .{ }^{13} \mathrm{C}-\mathrm{NMR}$ $\left(100 \mathrm{MHz}, \mathrm{CDCl}_{3}\right): \delta 193.8,181.3,165.9,135.0,133.4,131.9,129.8,127.8,127.2,126.5,121.8,120.6,99.6$, 38.5, 38.1, 31.8, 20.2, 13.8. HRMS (ESI): $[\mathrm{M}+\mathrm{Na}]^{+}$calcd for $\mathrm{C}_{19} \mathrm{H}_{20} \mathrm{~N}_{2} \mathrm{O}_{3}, 347.1474$; found, 347.1470.<smiles>O=C(O)C1=C(Nc2ccc3ccccc3c2)OCC1=O</smiles>

N-Cyclopropyl-2-(naphthalen-2-ylamino)-4-oxo-4,5-dihydrofuran-3-carboxamide (18); $\mathrm{Mp}: 140.8-41.6{ }^{\circ} \mathrm{C}$. ${ }^{1} \mathrm{H}-\mathrm{NMR}\left(400 \mathrm{MHz}, \mathrm{DMSO}-d_{6}\right): \delta 12.62(\mathrm{~s}, 1 \mathrm{H}), 8.78(\mathrm{~d}, J=3.6 \mathrm{~Hz}, 1 \mathrm{H}), 8.08-7.93(\mathrm{~m}, 4 \mathrm{H}), 7.69-7.54$ $(\mathrm{m}, 3 \mathrm{H}), 3.89(\mathrm{~s}, 2 \mathrm{H}), 2.82-2.77(\mathrm{~m}, 1 \mathrm{H}), 0.78-0.73(\mathrm{~m}, 2 \mathrm{H}), 0.56-0.50(\mathrm{~m}, 2 \mathrm{H}) .{ }^{13} \mathrm{C}-\mathrm{NMR}\left(100 \mathrm{MHz}, \mathrm{CDCl}_{3}\right)$ : $\delta$ 193.7, 181.2, 167.5, 134.9, 133.4, 131.8, 129.9, 127.9, 127.2, 126.5, 121.7, 120.5, 99.4, 38.6, 29.7, 21.6, 6.5. HRMS (ESI): $[\mathrm{M}+\mathrm{H}]^{+}$calcd for $\mathrm{C}_{18} \mathrm{H}_{16} \mathrm{~N}_{2} \mathrm{O}_{3}, 309.1161$; found, 309.1165 .<smiles>O=C(O)C1=C(Nc2ccc3ccccc3c2)OCC1=O</smiles>

N-(Cyclopropylmethyl)-2-(naphthalen-2-ylamino)-4-oxo-4,5-dihydrofuran-3-carboxamide (19); $\quad \mathrm{Mp:}$ 164.8-165.3 ${ }^{\circ} \mathrm{C} .{ }^{1} \mathrm{H}-\mathrm{NMR}\left(400 \mathrm{MHz}, \mathrm{DMSO}-d_{6}\right): \delta 12.68(\mathrm{~s}, 1 \mathrm{H}), 8.91(\mathrm{t}, J=5.6 \mathrm{~Hz}, 1 \mathrm{H}), 8.06-7.97$ $(\mathrm{m}, 4 \mathrm{H}), 7.62-7.55(\mathrm{~m}, 3 \mathrm{H}), 3.92(\mathrm{~s}, 2 \mathrm{H}), 3.19(\mathrm{t}, J=6.4 \mathrm{~Hz}, 2 \mathrm{H}), 1.06-0.99(\mathrm{~m}, 1 \mathrm{H}), 0.50-0.45(\mathrm{~m}, 2 \mathrm{H})$, 0.26-0.22 (m, 2H). ${ }^{13} \mathrm{C}-\mathrm{NMR}\left(100 \mathrm{MHz}, \mathrm{CDCl}_{3}\right): \delta 193.8,181.3,165.8,134.9,133.4,131.8,129.8,127.9$, 127.2, 126.5, 121.8, 120.6, 99.5, 43.0, 38.5, 10.9, 3.5. HRMS (ESI): $[\mathrm{M}+\mathrm{H}]^{+}$calcd for $\mathrm{C}_{19} \mathrm{H}_{18} \mathrm{~N}_{2} \mathrm{O}_{3}$, 323.1317; found, 323.1315.

Synthesis of Compound 20

CDI (1 mmol) was slowly added to a solution of ethyl 2-(naphthalen-2-ylamino)4-oxo-4,5-dihydrofuran-3-carboxylic acid ( $1 \mathrm{mmol})$ in dry DCM $(6 \mathrm{~mL})$ at $0{ }^{\circ} \mathrm{C}$ for $2 \mathrm{~h}$ with stirring. Then to the reaction mixture was added $80 \%$ hydrazine hydrate overnight with stirring at room temperature. After the reaction, the precipitation was filtered, dried, and purified by column chromatography (EA: 10:1, v/v MeOH) in 23-27\% in yield as a brown solid.<smiles>NNC(=O)C1=C(Nc2ccc3ccccc3c2)OCC1=O</smiles>

2-(Naphthalen-2-ylamino)-4-oxo-4,5-dihydrofuran-3-carbohydrazide (20); Mp: 167.3-167.9 ${ }^{\circ} \mathrm{C} .{ }^{1} \mathrm{H}-\mathrm{NMR}(400$ $\left.\mathrm{MHz}_{,} \mathrm{CDCl}_{3}\right): \delta 12.11(\mathrm{~s}, 1 \mathrm{H}), 8.02-7.91(\mathrm{~m}, 4 \mathrm{H}), 7.66-7.51(\mathrm{~m}, 3 \mathrm{H}), 5.58(\mathrm{~s}, 2 \mathrm{H}), 5.19(\mathrm{~s}, 2 \mathrm{H}) .{ }^{13} \mathrm{C}-\mathrm{NMR}$ $\left(100 \mathrm{MHz}_{1} \mathrm{CDCl}_{3}\right): \delta 194.7,185.4,162.7,133.5,132.6,131.5,132.2,128.4,128.2,127.5,127.2,124.2,120.3$, 79.9, 76.2. HRMS (ESI): $[\mathrm{M}+\mathrm{H}]^{+}$calcd for $\mathrm{C}_{15} \mathrm{H}_{13} \mathrm{~N}_{3} \mathrm{O}_{3}, 284.0957$; found, 284.0954 . 


\subsubsection{General Procedure for Target Compounds 21-26}

$\mathrm{NaOH}(1.5 \mathrm{mmol})$ was slowly added to a solution of $\mathrm{N}$-substituted-2-(substituted amino)-4-oxo-4,5-dihydrofuran-3-carboxamide $(1 \mathrm{mmol})$ in $\mathrm{EtOH}(6 \mathrm{~mL})$ at $0{ }^{\circ} \mathrm{C}$ with stirring. The reaction mixture was allowed to warm to $45^{\circ} \mathrm{C}$ for $1 \mathrm{~h}$ with stirring, and then paraformaldehyde $(\mathrm{POM})(1.2 \mathrm{mmol})$ was added for $8 \mathrm{~h}$ at $70^{\circ} \mathrm{C}$. After the resulting mixture was filtered, the filtrate was concentrated under reduced pressure and purified by column chromatography (PE: 3:1 $v / v$ EA) with $13.2-19.7 \%$ yield as a white solid.<smiles>CCN1CN(c2ccc3c(c2)CCC3)C2=C(C(=O)CO2)C1=O</smiles>

1-(2,3-Dihydro-1H-inden-5-yl)-3-ethyl-2,3-dihydrofuro[2,3-d]pyrimidine-4,5(1H,6H)-dione (21); $\quad$ Mp: 128.6-129.4 ${ }^{\circ} \mathrm{C} .{ }^{1} \mathrm{H}-\mathrm{NMR}\left(400 \mathrm{MHz}, \mathrm{CDCl}_{3}\right): \delta 7.32(\mathrm{~d}, J=8.0 \mathrm{~Hz}, 1 \mathrm{H}), 7.27(\mathrm{~s}, 1 \mathrm{H}), 7.16(\mathrm{~d}, J=8.0 \mathrm{~Hz}$, $1 \mathrm{H}), 4.22(\mathrm{q}, J=7.2 \mathrm{~Hz}, 2 \mathrm{H}), 4.17(\mathrm{~s}, 2 \mathrm{H}), 3.65(\mathrm{~s}, 2 \mathrm{H}), 2.89(\mathrm{t}, J=7.6 \mathrm{~Hz}, 4 \mathrm{H}), 2.09-2.02(\mathrm{~m}, 2 \mathrm{H}), 1.26$ $(\mathrm{t}, J=7.2 \mathrm{~Hz}, 3 \mathrm{H}) .{ }^{13} \mathrm{C}-\mathrm{NMR}\left(100 \mathrm{MHz}, \mathrm{CDCl}_{3}\right): \delta 190.9,183.5,165.6,145.7,144.2,135.8,125.4,123.6$, 121.6, 97.1, 88.3, 59.7, 38.4, 32.8, 32.4, 25.7, 14.9. HRMS (ESI): $[\mathrm{M}+\mathrm{H}]^{+}$calcd for $\mathrm{C}_{17} \mathrm{H}_{18} \mathrm{~N}_{2} \mathrm{O}_{3}, 299.1317$; found, 299.1325.<smiles>CN1CN(c2ccc3ccccc3c2)C2=C(C(=O)CO2)C1=O</smiles>

3-Methyl-1-(naphthalen-2-yl)-2,3-dihydrofuro[2,3-d]pyrimidine-4,5(1H,6H)-dione (22); Mp: 127.9-128.5 ${ }^{\circ} \mathrm{C}$. ${ }^{1} \mathrm{H}-\mathrm{NMR}\left(400 \mathrm{MHz}, \mathrm{CDCl}_{3}\right): \delta 8.11-7.90(\mathrm{~m}, 4 \mathrm{H}), 7.51-7.33(\mathrm{~m}, 3 \mathrm{H}), 5.61(\mathrm{~s}, 2 \mathrm{H}), 4.73(\mathrm{~s}, 2 \mathrm{H}), 3.27(\mathrm{~s}, 3 \mathrm{H})$. ${ }^{13} \mathrm{C}-\mathrm{NMR}\left(100 \mathrm{MHz}, \mathrm{CDCl}_{3}\right): \delta 191.1,183.4,165.5,135.4,133.3,132.3,129.8,128.4,128.2,127.5,127.2,124.2$, 123.6, 97.6, 86.3, 77.8, 38.5. HRMS (ESI): [M+ H] ${ }^{+}$calcd for $\mathrm{C}_{17} \mathrm{H}_{14} \mathrm{~N}_{2} \mathrm{O}_{3}$, 295.1004; found, 295.1011.<smiles>CCN1CN(c2ccc3ccccc3c2)C2=C(C(=O)CO2)C1=O</smiles>

3-Ethyl-1-(naphthalen-2-yl)-2,3-dihydrofuro[2,3-d]pyrimidine-4,5(1H,6H)-dione (23); Mp: 128.3-129.0 ${ }^{\circ} \mathrm{C}$. ${ }^{1} \mathrm{H}-\mathrm{NMR}\left(400 \mathrm{MHz}, \mathrm{CDCl}_{3}\right): \delta 8.11-7.90(\mathrm{~m}, 4 \mathrm{H}), 7.51-7.33(\mathrm{~m}, 3 \mathrm{H}), 5.61(\mathrm{~s}, 2 \mathrm{H}), 4.73(\mathrm{~s}, 2 \mathrm{H}), 3.27$ (s, 3H). ${ }^{13} \mathrm{C}-\mathrm{NMR}\left(100 \mathrm{MHz}, \mathrm{CDCl}_{3}\right): \delta 191.1,183.4,165.5,135.4,133.3,132.3,129.8,128.4,128.2,127.5$, 127.2, 124.2, 123.6, 97.6, 86.3, 77.8, 38.5. HRMS (ESI): $[\mathrm{M}+\mathrm{H}]^{+}$calcd for $\mathrm{C}_{17} \mathrm{H}_{14} \mathrm{~N}_{2} \mathrm{O}_{3}, 309.1161$; found, 309.1158.<smiles>CCCN1CN(c2ccc3ccccc3c2)C2=C(C(=O)CO2)C1=O</smiles> 
1-(Naphthalen-2-yl)-3-propyl-2,3-dihydrofuro[2,3-d]pyrimidine-4,5(1H,6H)-dione (24); Mp: $128.6-129.7{ }^{\circ} \mathrm{C}$. ${ }^{1} \mathrm{H}-\mathrm{NMR}\left(400 \mathrm{MHz}, \mathrm{DMSO}-d_{6}\right): \delta 7.92-7.84(\mathrm{~m}, 4 \mathrm{H}), 7.56-7.29(\mathrm{~m}, 3 \mathrm{H}), 4.51(\mathrm{~s}, 2 \mathrm{H}), 3.57(\mathrm{~s}, 2 \mathrm{H}), 3.05$ $(\mathrm{q}, J=6.4,2 \mathrm{H}), 1.69-1.63(\mathrm{~m}, 2 \mathrm{H}), 1.33(\mathrm{t}, J=7.2,3 \mathrm{H}) .{ }^{13} \mathrm{C}-\mathrm{NMR}\left(100 \mathrm{MHz}, \mathrm{DMSO}-d_{6}\right): \delta 193.6,182.4,162.3$, $135.4,133.3,132.3,131.8,128.4,128.2,127.5,127.2,124.2,123.6,97.6,38.6,38.5,14.9$. HRMS (ESI): [M + H] ${ }^{+}$ calcd for $\mathrm{C}_{17} \mathrm{H}_{18} \mathrm{~N}_{2} \mathrm{O}_{3}, 345.1317$; found, 345.1314.<smiles>O=C1COC2=C1C(=O)N(C1CC1)CN2c1ccc2ccccc2c1</smiles>

3-Cyclopropyl-1-(naphthalen-2-yl)-2,3-dihydrofuro[2,3-d]pyrimidine-4,5(1H,6H)-dione (25); Mp: 128.8-129.5 ${ }^{\circ} \mathrm{C} .{ }^{1} \mathrm{H}-\mathrm{NMR}\left(400 \mathrm{MHz}, \mathrm{DMSO}-d_{6}\right): \delta 8.08-7.93(\mathrm{~m}, 4 \mathrm{H}), 7.69-7.54(\mathrm{~m}, 3 \mathrm{H}), 3.89(\mathrm{~s}, 2 \mathrm{H}), 3.64(\mathrm{~s}, 2 \mathrm{H})$, 2.82-2.77 (m, 1H), 0.78-0.73 (m, 2H), 0.56-0.50 (m, 2H). ${ }^{13} \mathrm{C}-\mathrm{NMR}\left(100 \mathrm{MHz}, \mathrm{CDCl}_{3}\right): \delta 193.7,181.2$, 167.5, 134.9, 133.4, 131.8, 129.9, 127.9, 127.2, 126.5, 121.7, 123.5, 120.5, 99.4, 83.6, 77.4, 29.7, 21.6, 6.5. HRMS (ESI): $[\mathrm{M}+\mathrm{H}]^{+}$calcd for $\mathrm{C}_{19} \mathrm{H}_{16} \mathrm{~N}_{2} \mathrm{O}_{3}, 321.1161$; found, 321.1152.<smiles>NN1CN(c2ccc3ccccc3c2)C2=C(C(=O)CO2)C1=O</smiles>

3-Amino-1-(naphthalen-2-yl)-2,3-dihydrofuro[2,3-d]pyrimidine-4,5(1H,6H)-dione (26); Mp: 168.4-169.2 ${ }^{\circ} \mathrm{C}$. ${ }^{1} \mathrm{H}-\mathrm{NMR}\left(400 \mathrm{MHz}_{\mathrm{CDCl}}\right): \delta 10.33(\mathrm{~s}, 2 \mathrm{H}), 7.83-7.67(\mathrm{~m}, 4 \mathrm{H}), 7.65-7.43(\mathrm{~m}, 3 \mathrm{H}), 5.51(\mathrm{~s}, 2 \mathrm{H}), 4.88$ (s, 2H). ${ }^{13} \mathrm{C}-\mathrm{NMR}\left(100 \mathrm{MHz}, \mathrm{CDCl}_{3}\right): \delta$ 194.7, 185.4, 162.7, 133.5, 132.6, 131.5, 132.2, 128.4, 128.2, 127.5, 127.2, 124.2, 120.3, 87.3, 79.9, 76.2. HRMS (ESI): $[\mathrm{M}+\mathrm{H}]^{+}$calcd for $\mathrm{C}_{16} \mathrm{H}_{13} \mathrm{~N}_{3} \mathrm{O}_{3}, 296.0957$; found, 296.0957.

\section{Conclusions}

In this work, a series of brand-new scaffold PfDHODH-specific-inhibitor pyrimidone derivatives were obtained from docking analyses and structural optimizations. The most potent inhibitor 26 showed excellent inhibitory activity against PfDHODH $\left(\mathrm{IC}_{50}=23 \mathrm{nM}\right)$ and high species selectivity over $h \mathrm{DHODH}$. Through SAR studies, three preferential structural fragments were essential for these novel potent PfDHODH inhibitors: (1) bicyclic systems such as "naphthyl-like" substituents as the hydrophobic group; (2) two carbonyl groups in the dihydrofuranone ring oriented in the same direction and that formed hydrogen bonds with the polar residue (Arg265); (3) a hydrogen bond donor $\left(\mathrm{NH}_{2}\right.$ in compounds 20 and 26) that was important for the inhibitory activity to interact with the imidazole group of His185. The results might be valuable for the novel scaffold PfDHODH inhibitors to be developed as new antimalarial agents.

Author Contributions: H.L. and Z.Z. conceived and designed the experiments. L.X., W.L., H.S., and H.Z. performed the experiments. L.X., Y.D., and L.Z. analyzed the data. L.X., Y.D. wrote the paper.

Funding: This work was supported by the National Key Research and Development Program (Grant 2016YFA0502304), the National Natural Science Foundation of China (Grants 21372078 and 81302697), and the Fundamental Research Funds for the Central Universities.

Conflicts of Interest: The authors declare no conflict of interest.

\section{References}

1. Miller, L.H.; Ackerman, H.C.; Su, X.Z.; Wellems, T.E. Malaria biology and disease pathogenesis: insights for new treatments. Nat. Med. 2013, 19, 156-167. [CrossRef] [PubMed] 
2. White, N.J.; Pukrittayakamee, S.; Hien, T.T.; Faiz, M.A.; Mokuolu, O.A.; Dondorp, A.M. Malaria. Lancet 2014, 383, 723-735. [CrossRef]

3. World Health Organization. World Malaria Report 2016; WHO Press: Geneva, Switzerland, 2017.

4. Dondorp, A.M.; Yeung, S.; White, L.; Nguon, C.; Day, N.P.J.; Socheat, D.; von Seidlein, L. Artemisinin Resistance: Current Status and Scenarios for Containment. Nat. Rev. Microbiol. 2010, 8, 272-280. [CrossRef] [PubMed]

5. Bray, P.G.; Martin, R.E.; Tilley, L.; Ward, S.A.; Kirk, K.; Fidock, D.A. Defining the Role of PfCRT in Plasmodium falciparum Chloroquine Resistance. Mol. Microbiol. 2005, 56, 323-333. [CrossRef] [PubMed]

6. Mok, S.; Ashley, E.A.; Ferreira, P.E.; Zhu, L.; Lin, Z.; Yeo, T.; Chotivanich, K.; Imwong, M.; Pukrittayakamee, S.; Dhorda, M.; et al. Population transcriptomics of human malaria parasites reveals the mechanism of artemisinin resistance. Science 2015, 347, 431-435. [CrossRef] [PubMed]

7. Miotto, O.; Amato, R.; Ashley, E.A.; MacInnis, B.; Almagro-Garcia, J.; Amaratunga, C.; Lim, P.; Mead, D.; Oyola, S.O.; Dhorda, M.; et al. Genetic architecture of artemisinin-resistant Plasmodium falciparum. Nat. Genet. 2015, 47, 226. [CrossRef] [PubMed]

8. Menard, D.; Ariey, F. Towards real-time monitoring of artemisinin resistance. Lancet Infect. Dis. 2015, 15, 367-368. [CrossRef]

9. Hyde, J.E. Mechanisms of Resistance of Plasmodium falciparum to Antimalarial Drugs. Microbes Infect. 2002, 4, 165-174. [CrossRef]

10. McKie, J.H.; Douglas, K.T.; Chan, C.; Roser, S.A.; Yates, R.; Read, M.; Hyde, J.E.; Dascombe, M.J.; Yuthavong, Y.; Sirawaraporn, W. Rational Drug Design Approach for Overcoming Drug Resistance: Application to Pyrimethamine Resistance in Malaria. J. Med. Chem. 1998, 41, 1367-1370. [CrossRef] [PubMed]

11. Barnett, D.S.; Guy, R.K. Antimalarials in development in 2014. Chem. Rev. 2014, 114, 11221-11241. [CrossRef] [PubMed]

12. Wells, N.C.; Van Huijsduijnen, R.H.; Van Voorhis, W.C. Malaria medicines: A glass half full? Nat. Rev. Drug Discov. 2015, 15, 424-442. [CrossRef] [PubMed]

13. Burrows, N.; Burlot, E.; Campo, B.; Cherbuin, S.; Jeanneret, S.; Leroy, D. Antimalarial drug discovery the path towards eradication. Parasitology 2014, 141, 128-139. [CrossRef] [PubMed]

14. Baragana, B.; Hallyburton, I.; Lee, M.C.S.; Norcross, N.R.; Grimaldi, R.; Otto, T.D. A novel multiple-stage antimalarial agent that inhibits protein synthesis. Nature 2015, 522, 315-320. [CrossRef] [PubMed]

15. Efficacy and safety of RTS,S/AS01 malaria vaccine with or without a booster dose in infants and children in Africa: fi nal results of a phase 3, individually randomised, controlled trial. Lancet 2015, 386, 31-45.

16. Fagan, R.L.; Nelson, M.N.; Pagano, P.M.; Palfey, B.A. Mechanism of Flavin Reduction in Class 2 Dihydroorotate Dehydrogenases. Biochemistry 2006, 45, 14926-14932. [CrossRef] [PubMed]

17. Palfey, B.A.; Björnberg, O.; Jensen, K.F. Specific Inhibition of a Family 1A Dihydroorotate Dehydrogenase by Benzoate Pyrimidine Analogues. J. Med. Chem. 2001, 44, 2861-2864. [CrossRef] [PubMed]

18. Phillips, M.A.; Rathod, P.K. Plasmodium dihydroorotate dehydrogenase: a promising target for novel anti-malarial chemotherapy. Infect. Disord. Drug Targets 2010, 10, 226-239. [CrossRef] [PubMed]

19. Wu, T.; Nagle, S.; Aavait, K.; Chatterjee, A. Road Towards New Antimalarials-Overview of the Strategies and their Chemical Progress. Curr. Med. Chem. 2011, 18, 853-871. [CrossRef] [PubMed]

20. Munier-Lehmann, H.; Vidalain, P.-O.; Tangy, F.; Janin, Y.L. On Dihydroorotate Dehydrogenases and Their Inhibitors and Uses. J. Med. Chem. 2013, 56, 3148-3167. [CrossRef] [PubMed]

21. Coteron, J.M.; Marco, M.A.; Esquivias, J.; Deng, X.; White, K.L.; White, J.; Koltun, M.; El Mazouni, F.; Kokkonda, S.; Katneni, K.; et al. Structure-Guided Lead Optimization of Triazolopyrimidine-Ring Substituents Identifies Potent Plasmodium falciparum Dihydroorotate Dehydrogenase Inhibitors with Clinical Candidate Potential. J. Med. Chem. 2011, 54, 5540-5561. [CrossRef] [PubMed]

22. Malmquist, N.A.; Gujjar, R.; Rathod, P.K.; Phillips, M.A. Analysis of Flavin Oxidation and Electron-Transfer Inhibition in Plasmodium falciparum Dihydroorotate Dehydrogenase. Biochemistry 2008, 47, 2466-2475. [CrossRef] [PubMed]

23. Herrmann, M.L.; Schleyerbach, R.; Kirschbaum, B.J. Leflunomide: An Immunomodulatory Drug for the Treatment of Rheumatoid Arthritis and Other Autoimmune Diseases. Immunopharmacology 2000, 47, $273-289$. [CrossRef] 
24. Baumgartner, R.; Walloschek, M.; Kralik, M.; Gotschlich, A.; Tasler, S.; Mies, J.; Leban, J. Dual Binding Mode of a Novel Series of DHODH Inhibitors. J. Med. Chem. 2006, 49, 1239-1247. [CrossRef] [PubMed]

25. Kulkarni, O.P.; Sayyed, S.G.; Kantner, C.; Ryu, M.; Schnurr, M.; Sardy, M.; Leban, J.; Jankowsky, R.; Ammendola, A.; Doblhofer, R.; et al. 4SC-101, A Novel Small Molecule Dihydroorotate Dehydrogenase Inhibitor, Suppresses Systemic Lupus Erythematosus in MRL-(Fas)lpr Mice. Am. J. Pathol. 2010, 176, 2840-2847. [CrossRef] [PubMed]

26. Baldwin, J.; Michnoff, C.H.; Malmquist, N.A.; White, J.; Roth, M.G.; Rathod, P.K.; Phillips, M.A. High-throughput Screening for Potent and Selective Inhibitors of Plasmodium falciparum Dihydroorotate Dehydrogenase. J. Biol. Chem. 2005, 280, 21847-21853. [CrossRef] [PubMed]

27. Patel, V.; Booker, M.; Kramer, M.; Ross, L.; Celatka, C.A.; Kennedy, L.M.; Dvorin, J.D.; Duraisingh, M.T.; Sliz, P.; Wirth, D.F. Identification and Characterization of Small Molecule Inhibitors of Plasmodium falciparum Dihydroorotate Dehydrogenase. J. Biol. Chem. 2008, 283, 35078-35085. [CrossRef] [PubMed]

28. Phillips, M.A.; Gujjar, R.; Malmquist, N.A.; White, J.; El Mazouni, F.; Baldwin, J.; Rathod, P.K. Triazolopyrimidine-Based Dihydroorotate Dehydrogenase Inhibitors with Potent and Selective Activity against the Malaria Parasite Plasmodium falciparum. J. Med. Chem. 2008, 51, 3649-3653. [CrossRef] [PubMed]

29. Jimenez-Diaz, M.B.; Mulet, T.; Viera, S.; Gomez, V.; Garuti, H.; Ibanez, J.; Alvarez-Doval, A.; Shultz, L.D.; Martinez, A.; Gargallo-Viola, D.; et al. Improved murine model of malaria using Plasmodium falciparum competent strains and non-myelodepleted NOD-scid IL2Rgammanull mice engrafted with human erythrocytes. Antimicrob. Agents Chemother. 2009, 53, 4533-4536. [CrossRef] [PubMed]

30. Phillips, M.A.; White, K.L.; Kokkonda, S.; Deng, X.; White, J.; El Mazouni, F.; Marsh, K.; Tomchick, D.R.; Manjalanagara, K.; Rudra, K.R.; et al. A Triazolopyrimidine-Based Dihydroorotate Dehydrogenase Inhibitor with Improved Drug-like Properties for Treatment and Prevention of Malaria. ACS Infect. Dis. 2016, 2, 945-957. [CrossRef] [PubMed]

31. Xu, M.; Zhu, J.; Diao, Y.; Zhou, H.; Ren, X.; Sun, D.; Huang, J.; Han, D.; Zhao, Z.; Zhu, L.; et al. Novel selective and potent inhibitors of malaria parasite dihydroorotate dehydrogenase: discovery and optimization of dihydrothiophenone derivatives. J. Med. Chem. 2013, 56, 7911-7924. [CrossRef] [PubMed]

32. Woody, S.; Tyler, D.; Matthew, P.J.; Richard, A.F.; Ramy, F. Novel Procedure for Modeling Ligand/Receptor Induced Fit Effects. J. Med. Chem. 2006, 49, 534-553.

33. Baker, N.A.; Sept, D.; Joseph, S.; Holst, M.J.; McCammon, J.A. Electrostatics of nanosystems: application to microtubules and the ribosome. Proc. Natl. Acad. Sci. USA 2001, 98, 10037-10041. [CrossRef] [PubMed]

34. Dolinsky, T.J.; Nielsen, J.E.; McCammon, J.A.; Baker, N.A. PDB2PQR: An automated pipeline for the setup of Poisson-Boltzmann electrostatics calculations. Nucleic Acids Res. 2004, 32, W665-W667. [CrossRef] [PubMed]

35. Dolinsky, T.J.; Czodrowski, P.; Li, H.; Nielsen, J.E.; Jensen, J.H.; Klebe, G.; Baker, N.A. PDB2PQR: expanding and upgrading automated preparation of biomolecular structures for molecular simulations. Nucleic Acids Res. 2007, 35, W522-W525. [CrossRef] [PubMed]

36. Hansen, M.; Le Nours, J.; Johansson, E.; Antal, T.; Ullrich, A.; Löffler, M.; Larsen, S. Inhibitor Binding in a Class 2 Dihydroorotate Dehydrogenase Causes Variations in the Membrane-Associated N-Terminal Domain. Protein Sci. 2004, 13, 1031-1042. [CrossRef] [PubMed]

37. Peterson, E.A.; Teffera, Y.; Albrecht, B.K. Discovery of Potent and Selective 8-Fluorotriazolopyridine c-Met Inhibitors. J. Med. Chem. 2015, 58, 2417-2430. [CrossRef] [PubMed]

38. Knecht, W.; Henseling, J.; Löffler, M. Kinetics of Inhibition of Human and Rat Dihydroorotate Dehydrogenase by Atovaquone, Lawsone Derivatives, Brequinar Sodium and Polyporic Acid. Chem. Biol. Interact. 2000, 124, 61-76. [CrossRef]

39. McLean, J.E.; Neidhardt, E.A.; Grossman, T.H.; Hedstrom, L. Multiple Inhibitor Analysis of the Brequinar and Leflunomide Binding Sites on Human Dihydroorotate Dehydrogenase. Biochemistry 2001, 40, 2194-2200. [CrossRef] [PubMed]

Sample Availability: Samples of the compounds 11-26 are available from the authors. 